\title{
A New Type of Spermogonium and Fertilization in Collema.
}

\author{
BY
}

FREDA M. BACHMANN.

With Plate LXIX.

THE question as to the true nature of the so-called spermatia in Lichens, 1 many Pyrenomycetes, Rusts, \&c., connected as it is with the general question of functional sexuality in the Ascomycetes, still remains an open one in the minds of some students of the Fungi. ${ }^{1}$ I have undertaken further studies on the Collemaceae with a view to throwing light on both these problems.

What Tulasne has called the spermogonia of Lichens were thought by Fries (15) to be aborted apothecia. Flotow (14), a few decades later, describes them as perithecia without asci or paraphyses and containing only atom-like sporidia. Itzigsohn (21) believed the spermatia were motile and similar to the male cells of Polytrichum and Marchantia, hence he called them spermatozoids and called the spermogonia antheridia. A few months later, in a second paper (22), he confirms his earlier observations, but also adds that Rabenhorst and Kuitzing had written him of their failure to see any movement of these small cells, and that Flotow had observed a movement of the cells but, finding the same in material which had been in the herbarium for twenty years, had concluded that it was only a molecular movement. A year later, in a letter to Itzigsohn (23), Rabenhorst writes that he saw such a movement as had been described by Itzigsohn.

Tulasne (35), failing to see any resemblance between these flask-shaped filamentous structures in Lichens and the antheridia of Mosses and Hepatics, and not finding their contents motile, proposed to call them spermogonia and the small cells produced in them and set free through the ostiole spermatia. He figured the spermogonia and spermatia for about fifty

${ }^{1}$ Klebahn, H.: Die wirtswechselnden Rostpilze. Berlin, I904. Bitter, Georg: Zur Morphol. u. Systematik v. Parmelia, Untergattung Hypogymnia. Hedwigia, xl, IgoI, pp. I 7 I-274.

[Annals of Botany, Vol. XXVI. No. CIII. July, I912.] 
different species of Lichens. He found that the size and shape of the spermatia vary in the different species, but in every case he found them borne on specialized hyphae, the spermatiophores, in pocket-like depressions in the thallus, the spermogonia, and finally extruded through the ostiole of the spermogonium on the surface of the thallus. In a later paper (36) he described and figured spermatia in Fungi other than Lichens. Tulasne thought spermatia differed from conidia in that they would not germinate. He believed the spermatia were male cells, and the asci female cells.

Cornu (8) succeeded in germinating the spermatia of a number of Ascomycetes other than Lichens, and concluded from his observations that spermatia are a kind of conidia. He continued to use the word spermatia, but would have it apply only to very small conidia which because of their very small size could easily be carried long distances.

Stahl (30) was the first to recognize the true female reproductive organ in the Lichens and to determine the real function of the spermatia. In the gelatinous Lichens which he investigated, Collema pulposum, C.microphyllum, Physma compactum, and Synechoblastus conglomeratus, the female organ or carpogone, as Stahl calls it, is a septate, spirally wound hypha at its base with a long terminal portion directed towards and protruding somewhat above the surface of the thallus. Stahl called this terminal part the trichogyne, a name which had originally been given by Bornet and Thuret (7) to a similar structure in the red Algae. In these Lichens Stahl found the spermatia to be small oval cells borne in spermogonia. Stahl says it is easy to believe that the spermatia which are extruded in large numbers from the neck of the spermogonium are spread over the surface of the thallus by means of rain-drops. At least he finds the end cell of the trichogynes which protrudes above the surface of the thallus with several spermatia clinging to it. He also finds that the spermatia become attached very firmly to the trichogyne, so that neither water nor a jarring of the cover-glass will detach them. He has figured three cases in which the wall has been dissolved between the spermatium and the trichogyne, resulting in a continuity of the protoplasm of the two cells. Stahl found that after a spermatium had fused with a trichogyne, the cross-walls of the trichogyne became gelatinized, and the cells of the spirally wound portion, or ascogone, increased in size. From this basal portion, as Jancewski (24) had described for Ascobolus and Kihlman (25) for Pyronema, came the ascogenous hyphae. That the spermatia are the male cells of Lichens and that we have in spermatia, trichogyne, and carpogone a genuine functional sexual apparatus seems conclusive, in spite of the attempts of Brefeld, Möller, and others many times reviewed, ${ }^{1}$ to

1 Blackman, V. H.: On the Fertilization, Alternation of Generations, and General Cytology of the Uredineae. Annals of Bot., xviii, 1904. Harper, R. A. : Sexual Reproduction in Pyronema confluens and the Morphology of the Ascocarp. Annals of Bot., xiv, 1900. Baur, Erwin: Die Anlage und Entwickelung einiger Flechtenapothecien. Flora, lxxxviii, I888, pp. 3 ${ }^{\text {I9-32. }}$ 
weaken the evidence. Stahl notes that Collema pulposum is frequently entirely sterile, though well provided with trichogynes. In these cases spermogonia were lacking or were represented only by a few small rudiments embedded in the thallus. Whether such cases indicate an approach in the European forms of $C$. pulposum to the conditions which I shall describe below for the Wisconsin material is an interesting question.

Stahl's work on the Collemaceae was later confirmed by Sturgis and Baur. Sturgis (31) noted the presence of spermogonia in some species which he investigated, and very briefly and incompletely described the spermatia and the origin of the spermogonia. In Collema chalazanum, Ach., C. pulposum, Ach., C. nigrescens, (Huds.) Ach., and Leptogium myochorum, Tuck., he found the ascogones, trichogynes, and spermogonia exactly as described by Stahl. Baur's (4) results on Collema crispum are likewise in agreement with Stahl's. Stahl's observations have also been confirmed wholly or in part for a number of Lichens other than the gelatinous types in the work of Lindau (26), Baur (5 and 6), and Darbishire (10). Spermatia have not been found in all Lichens. Fünstuick (16) concludes that the genera Peltigera and Peltidea have no spermatia, and he described a vegetative origin of the apothecia in Peltigera malacea, P. canina, Peltidea apthosa, and $P$. venosa.

In all Lichens in which spermatia have been found up to the present time these cells are borne near the surface of the thallus in large numbers in cup-like depressions, the spermogonia, as described by Tulasne in I 850 . The trichogynes, wherever they have been found, grow up to the surface of the thallus, protrude a short distance, and there fuse with the spermatia which are brought to them probably by rain as suggested by Stahl. In the Collema which I have studied I find no superficial spermogonia.

My material was obtained from a sandstone cliff overlooking Lake Mendota and from the bluffs along the Wisconsin River near Lone Rock, Wisc. The lichen has also been collected at Blue Mounds, Wisc. There has always been plenty of material for fixing and sectioning, but never an abundance for herbarium specimens. Only small amounts collected at different times have been preserved dry. Preissia, Conocephalus, Marchantia, Mosses, and a few small flowering plants, mostly in the sunnier places, are found in the same habitats. The Collema material grows in the more shaded parts or where it is partly shaded by flowering plants. Growth of the thalli is interrupted only in the winter and during very dry weather in summer. In the spring, as soon as the snow melts and the ground is thawed, the thalli resume growth.

Prof. Farlow has very kindly examined my material and finds that it agrees very well with Tuckerman specimens of Collema pulposum, (Bernh.) Ach., noting, however, that it approaches $C$. tenax, (Sw.) Ach. In view of the new results which I have obtained and which are unlike anything 
found by Stahl, Sturgis, Tulasne, or others who have described either the carpogones or spermogonia of $C$. pulposum, the identification of the species has become a question of prime importance. It appears that what is known as C. pulposum, (Bernh.) Ach., varies considerably. Acharius (2) gives five varieties: crispum, cristatum, aphaneum, granulatum, and prasinum. Schaerer (29), in 1842, gives two varieties, vulgaris and prasina. Nylander (28) gives five: formosum, compactum, hydrocharum, prasinum, and tenax. Tuckerman (34) writes of $C$. pulposum, 'It is without doubt largely represented in North America, but abounds peculiarly in difficulties which do not appear to be as yet resolvable in Europe; as certainly not here. With present knowledge, beside what may vaguely be taken for true $C$.pulposum, the group may be considered as represented with us by the five following, at least sub-species, the claims of which to higher rank are left open.' These five are: C. tenaxum, (Tuck.), C. tenax, (Sw.) Ach., C.crispum, Borr., C. limosum, Ach., C. coccophorum, Tuck., and C.plicatile, Schaer.

The form of C. pulposum which I have studied may be described as follows: Thallus, when young orbicular, later becoming quite irregular, I 5 to $60 \mathrm{~mm}$. long, upper surface smooth or sometimes granuloso-lobulate, especially about the immersed apothecia; when wet gelatinous but quite firm, dark olive green above and below, or lead-coloured or yellowish green; when dry brittle, much shrivelled and almost black, or, especially in case of yellowish green thalli, the shape and colour little changed in drying; attached to the soil by numerous light to dark brown simple or branched rhizoids 4 to 7 microns in diameter; marginal lobes more or less expanded, sometimes repand-crenate, sometimes imbricated, I to I. $5 \mathrm{~mm}$. thick, sometimes showing a rosulate arrangement, or both marginal and central lobes somewhat erect; Nostoc filaments more numerous near the surfaces ; apothecia developing quite close together and almost covering the central part of the thallus, rounded, $\mathrm{I} \cdot 5$ to $4.5 \mathrm{~mm}$. in diameter; when young immersed in slightly raised areas of the thallus, sessile, at first concave, later concave or convex; disc at first pale green, later reddish-brown, margin from entire becoming rugose-crenate; hypothecium almost colourless to light brown; hymenium light brown above; paraphyses brown in potassium iodide, septate, 2 to 3 microns wide and I I o to I 60 microns long, simple or branched near the base, tips somewhat enlarged ; asci clavate, blue in potassium iodide, 18 to 25 microns wide and 95 to 140 microns long; spores 8 , hyaline, brown in potassium iodide, oblong-ellipsoid, muriform, io or I 8 celled, I 7 to 30 microns long and 7 to I 3.5 microns wide.

Stahl and those who have described the spermogonia in Collema pulposum may have had what Tuckerman (34) designates as the 'true C.pulposum'. Sturgis worked with some American form. He states that his observations agree in all respects with those of Stahl. He gives but one 
figure, and this is of a young carpogone which has not yet developed a trichogyne.

The technique necessary for a cytological study of the Lichens has been found very difficult by most investigators. Baur found Endocarpon miniatum the only lichen which he could cut in paraffin. For others he found it necessary to cut in celloidin after first saturating the block with glycerine. In this way he succeeded in getting sections 10 to 25 microns thick.

For killing and fixing my material I have used Flemming's medium solution of chrom-osmic acetic acids and a I per cent. solution of platinic chloride with very satisfactory results. After washing in water, the material was dehydrated in the different grades of alcohol. Better results in sectioning were obtained if the dehydration was somewhat rapid up to 95 per cent. alcohol. The use of cedar oil makes the material less brittle than xylol or chloroform. The difficulties of other students in this respect were probably due to failure to dehydrate perfectly and to secure perfect infiltration. I have left the material from eight to twelve hours in cedar oil and for the same length of time in equal parts cedar oil and $45^{\circ}$ paraffin. The temperature of the paraffin bath should not greatly exceed the melting point of the paraffin. Perfect infiltration has been secured in four to five days in melted paraffin before embedding. Serial sections 5 to 25 microns thick were cut without any difficulty. Some of the slides were stained with Heidenhain's iron-hematoxylin, but the triple stain of Flemming gave the most satisfactory results.

In microscopic section the thallus is seen, as is well figured by Stahl, to be composed of a network of anastomosing fungal hyphae embedded in the jelly of the algal symbiont, Nostoc. The Nostoc filaments are much more abundant near the surface of the thallus, but are also scattered throughout its entire thickness (Pl. LXIX, Fig. I).

Ascogones are formed as soon as growth begins in the spring, and in May or June are very abundant in both early and later stages of development. In lobes of small fruiting thalli about half of the sections $(25$ microns thick) show parts of ascogones. In order to facilitate tracing the ascogones and trichogynes I have cut some sections quite thick. With some practice in staining, these thick sections stain very well for cytological as well as morphological study. The ascogones are found singly or more often in groups of three or four and are usually about a fourth of the thickness of the thallus below the upper surface. Carpogones have been found in groups in a number of Lichens. In Lecanora subfusca, L., Baur (6) and Lindau (26) found the carpogones in groups of five to ten; in Endocarpon miniatum, L., Baur (6) found three to eight. Except in one instance in the Collemas, Stahl found that the apothecia arise from a single carpogone, and he has figured the carpogones of Collema as isolated. In Physma compactum he found several trichogones in a single apothecium. In this 
species the apothecium is compound, since it develops from several carpogones. Very often at least, the filament which is to bear one or more carpogones is differentiated from the other hyphae by having shorter, broader cells. From this filament branches arise which coil at once. The cells of a coil are short and broad, isodiametric or very slightly elongated. As the carpogone grows, the cells composing it elongate somewhat and become two to three times as long as they are wide (Figs. I and 2). There are from fifteen to twenty-five cells in a coil. Stahl found the number varied from twelve to twenty in Collema microphyllum, and for Collema crispum Baur (4) gives the number as fifteen to twenty. The number of spirals varies from two to about three and a half. Sometimes the spiral is loosely and unevenly coiled (Fig. 4), more often it is coiled quite evenly (Fig. 3). This is in agreement with what has been found in other species of the genus.

Very shortly after the spirals are formed, the terminal cell begins to elongate. It is 3 to 5 microns wide and reaches a length of I 75 to 280 microns (Figs. 2, 3, and 4). The terminal cell of a carpogone is always easily distinguished from the vegetative hyphae in a stained section by its colour. It is coloured more deeply blue than the other hyphae. It is sometimes reddish if the exposure to the safranin has been prolonged, but very seldom appears stained by the orange. Also the width of the cell is slightly greater than that of most vegetative hyphae, and these two facts, with the absence of cross-walls, make it very conspicuous. Tracing this cell from section to section one finds that it does not grow vertically upwards towards the surface of the thallus, but more or less horizontally or parallel to the plane of the thallus. It is not straight, but often somewhat winding. Often several of the cells next to the terminal trichogyne cell are elongated more than those further back in the coils of the carpogone.

Stahl has distinguished three parts in the carpogone-the terminal cell which is the receptive portion, the ten to twenty cells (number varying with the species) next the terminal cell which is the conductive portion, and the coils at the base or ascogone from which later the ascogenous hyphae develop. The carpogone, then, according to Stahl, is composed of ascogone and trichogyne, and the latter again is divided according to function into a receptive and conductive part. In my material these three parts may be readily distinguished. The long terminal cell is the receptive cell, but of course it is largely concerned in conducting the male nucleus to the ascogone. Even before fertilization, then, the carpogones are easily recognized and distinguished from the vegetative parts in the section by the coiled basal portion and the long terminal cell.

As noted above, no superficial spermogonia have been observed in my material. The spermatia are, however, found abundantly in the same thalli, and in the same part of the thallus in which the carpogones are found. 
There are no flask-shaped spermogonia such as have been described for other Lichens. The spermatia are simply borne in scattered groups embedded in the thallus at a depth of 100 to 300 microns (Fig. I). They are oval or pear-shaped cells, often more or less constricted in the centre (Figs. 2, 4, and 5). They are 2 to 3 microns wide and 9 to 12 microns long. They stain lightly. There may be few in a group-only two (Fig. 3), or as many as fourteen or fifteen may be found in a single cluster. They are borne terminally if only one or two are present, or they may be both terminal and lateral if more are present. They arise by what appears to be a process of budding from certain slender lightly staining hyphae. The cells of the hyphae bearing them are often much shorter than the spermatia ; sometimes the spermatia are long and narrow. Lindau (26) has described the spermatia of Anaptychia ciliaris as small cells, borne on many-celled sterigmata from which they are constricted off. He does not figure them. In Collema pulposum, Ach., according to Tulasne, the spermogonia are sunken in the thallus and contain many branched septate filaments, the spermatiophores, which bear the spermatia laterally and terminally. In Collema cheileum, Ach., the filaments are more branched and the spermogonia not sunken in the thallus. In Tulasne's figure the spermatia are borne at the sides and ends of the intercalary cells very much as I find them in my material. Tulasne's figure of $C$. pulposum shows in some cases two spermatia arising from the same cell. The spermatia of $C$. jacobaeifolium and C. pulposum are small oval cells, sometimes constricted in the centre. Tulasne (35) gives the length of the spermatia of $C$. nigrescens as 4 to 5 microns. The spermatia of $C$. microphyllum, according to Stahl, are often constricted in the centre; those of Physma compactum are ovoid. In C. crispum, Ach., Baur (4) found the spermatia to be small ovoidal cells. He does not give the size nor tell how they are borne.

Sometimes the spermatia in my material form such dense groups that the exact manner of their origin is difficult to determine. Very commonly they are found free, suspended in the jelly of the Nostoc. Apparently when mature they are not at all firmly attached to the filament on which they are borne. There is no evidence in such sections that they have been torn away by the process of fixing and cutting.

As noted above, the trichogynes in my material do not grow vertically upwards to the surface of the thallus, but remain embedded in it, extending horizontally or in the plane of the thallus. If we follow them in their course the striking fact is at once noted that they grow towards the groups of spermatia. In fact, the groups of spermatia are most easily found by tracing the long terminal cells of trichogynes which are growing towards them. These trichogynes may, of course, run through several sections 25 microns thick. As one is nearing that section in which the spermatia are present, frequently more and more parts of trichogynes are 
seen. Where there are only one or two spermatia in a group, a single trichogyne grows in that direction (Fig. 3); if a larger number of spermatia are present there is a correspondingly larger number of trichogynes converging towards them (Figs. 2 and 5). Frequently the trichogynes from ascogones originating rather close together grow towards different groups of spermatia.

We have thus a complete submergence of the sexual apparatus in the tissues of the thallus and the consequent complete disappearance of the protective spermogonium about the groups of spermatia (Fig. I). The trichogynes seek out the spermatia which have lost even their passive motility by means of water or insects.

The end of the trichogyne is oval, and becomes closely appressed to and flattened against the wall of the spermatium. In some cases the tip of the trichogyne coils closely about half-way around the spermatium, and the opening later between the trichogyne and the spermatium is at the tip of the trichogyne and about in the centre, and on the side of the spermatium. This is similar to the behaviour of the conjugating tube in Pyronema as described by Harper (17). Here, too, the egg-cell has produced a structure which grows out to the antheridium and coils partly around it before the conjugation pore is formed. Harper says the conjugating tube applies itself closely to the surface of the antheridium and becomes curved, and sometimes even hook-shaped, to conform to the surface of the antheridium. This behaviour is, in many cases, exactly like that of the trichogyne in the form of Collema pulposum here described. In other cases it does not coil around the spermatium, but becomes attached at the side or at the end of the spermatium (Fig. 5). In one case a trichogyne was found with two free spermatia attached to it. The figures of Stahl and Baur show the spermatium attached to the trichogyne a short distance from the tip of the latter and the opening at the side and near one end of the spermatium. In this species there is no coiling of the trichogyne around the spermatium.

The several cells next the terminal cell of the trichogyne now begin to exhibit characteristic changes. Up to this time the cross-walls have appeared thin and sharp in outline. As Stahl observed, however, the crosswalls now apparently gelatinize and become very much thickened. This thickening is greatest in the centre of the septum, so that biconvex lensshaped walls result; only occasionally are they biconcave (Figs. 3 and 4). This process begins in the most distal of these cells and progresses towards the ascogone. The walls nearest the ascogone appear as a thick gelatinous plate with a broad opening in the centre. My results on these points are in agreement with those of Stahl and Baur. In my preparations made with the triple stain these swollen gelatinous cross-walls take a deep orange colour with even a very short exposure to orange $G$. This makes these cells extremely conspicuous and easy to find in the sections. The changes 
in the thickness of the walls and their affinity for the orange is very similar to that described by Harper (18) for the antheridium of Phyllactinia, where, after the conjugation pore is closed, the wall of the antheridium increases in thickness by what seems to be mucilaginous degeneration. The swelling, too, is towards the interior of the cell. There is, however, a difference in that it is only the cross-walls of the trichogyne which gelatinize; the side walls remain as before. In Phyllactinia the thickening is less in the region of the closed conjugation pore and greatest on the wall of the antheridium opposite this pore. The blue-staining terminal cells and the brown crosswalls of the trichogynes are very conspicuous even after the apothecium has been formed. The cells of the trichogyne maintain their cylindrical shape for some time, but by the time the thickening of the cross-walls is greatest the protoplasm of the cells has become denser, the plasma membrane is pulled away from the side walls, and these walls begin to bend in towards the centre of the cell, giving the cell somewhat the shape of an hour-glass. The cells are even more conspicuous now because their apparently disintegrating protoplasmic masses stain deep red. The cross-walls are gelatinized but remain as wide as ever.

This change in the shape of the trichogyne cells was observed by Stahl, who thought it was connected with a loss of water and hence of turgidity. The disintegrating masses of protoplasm have the same appearance as that described for the antheridial cell of the Mildews and of the conjugation tube of Pyronema. Harper found that the cell sap disappears, allowing the denser portions to form a homogeneous mass which has then an affinity for the safranin. Harper also observed that as disintegration continued the mass stained less deeply, but that the brown walls were still conspicuous. This is true for my material. The brown cross-walls are still evident when the part of the cell between is scarcely noticeable.

As to the sexual nature of the structures described, my investigations confirm those of Stahl, Baur, and Darbishire, and leave no doubt as to the functions of the trichogyne and spermatia. The behaviour of the trichogyne in this Collema should put an end to the idea of the trichogyne being either a respiratory apparatus or a boring organ. It is very evident here that the trichogyne is exactly what it is in the red Algae, a structure developed from the egg-cell to conduct the male nucleus to the egg-cell. The very apparent attraction of the trichogynes to the spermatia, and the later changes in the ascogone and trichogyne, show plainly also that the reproductive organs are functional.

We may summarize the differences in the sexual apparatus of this form of Collema pulposum and that of all other Lichens so far described as follows: (I) The spermatia are reduced in numbers and are not enclosed in spermogonia. (2) The spermatia are embedded deep within the thallus and are never set free on its surface. (3) The trichogyne has fewer cells 
and an unusually long terminal cell. (4) The trichogyne grows towards and seeks out the male cells. In all other Lichens the spermatia are borne in large numbers in specialized organs, the spermogonia, and are extruded through the ostiole on the surface of the thallus, then to be carried by rain, dew, or possibly wind or insects, to the trichogyne, the tip of which is also above the surface of the thallus. If fertilization by means of water is more primitive, these then have more nearly retained or reverted to the aquatic habits of their ancestors in the production of large numbers of male cells and in the method by which the egg-cell is fertilized.

The conditions found in Collema pulposum have probably been developed with the land habit and approach those found in Pyronema and the Erysipheae. The greater activity of the trichogyne results in a certainty of fertilization which makes the production of a large number of male cells entirely unnecessary. There is here the same certainty of fertilization which exists in Pyronema, where there is usually but one and never more than two male cells for each female cell. The disappearance of large spermogonia is correlated with the certainty of fertilization and the diminished number of spermatia. It is plain, however, that this is not a reduced or vegetative fertilization in Blackman's sense. The male cells are just as highly specialized as in other Lichens or the Red Algae. Whenever it has been possible to be certain of the manner in which the spermatia are borne, this has been found to be similar to that of other Collemas as well as of many other Lichens. The short, broad, faintly staining cells of the spermatiophores with delicate cross-walls are quite different in appearance from the elongated, easily stained cells with heavy septa of the vegetative hyphae. These spermatia are also similar to those borne in spermogonia in the apparent readiness with which they are separated from their place of origin. The limited size, the shape, the often constricted centre, the attraction for the trichogynes, and the fact that they are formed only at a particular stage in the life-history of the lichen, all show that they are specialized cells with a definite sex function. The trichogyne does not fuse with the vegetative hyphae, but seeks out these specialized cells exactly as in the case of all other sexual fusions.

In view of what has been described of the relation of spermatia and trichogynes by Stahl, Sturgis, Lindau, Baur, and Darbishire, it would seem as if the sexual nature of spermatia could not be doubted. Still Fink (13), after noting Möller's results in germinating spermatia, writes: 'This would seem to indicate that the spermatia, if they are sexual cells, have become so degenerate in certain Lichens as to lose their sexual function, becoming capable at the same time of reproducing vegetatively.' It seems very clear that the spermatia in my material are entirely homologous with those borne in the spermogonia of other Collemas, and it is impossible to conceive, after what has been described above of their behaviour in this 
species, that they are asexual conidia. Möller's results as to germination may or may not be correct, but the conditions in Collema pulposum certainly give a final and complete demonstration that the spermatia of the Lichens are male gametes and not asexual conidia. Even the author of such a tenuous hypothesis as that of the boring function of the trichogyne will hardly argue that these few cells buried deep in the thallus and never set free have their natural function as spores for the rapid asexual spread of the fungus.

The conditions in the lichen here described throw new light on the old and much discussed question as to the relationship of the red Algae and the Ascomycetes. Harper (17), as have others before, has emphasized the fact that Pyronema, like the Laboulbeniaceae, forms an interesting link between the Lichens and the red Algae because of its conjugating tube. In those red Algae which have been investigated, the trichogyne is a tubular outgrowth from the egg-cell. In Pyronema this outgrowth is separated from the eggcell by a wall. In the Lichens there are perhaps several cells between the receptive portion and the egg-cell. Collema pulposum is intermediate between those Lichens in which the trichogyne is composed of many small cells and Pyronema, where it is but one cell. But this species resembles Pyronema more than other Lichens, especially in the greater activity of the trichogyne and the manner in which it grows towards and coils about a spermatium, and in the reduced number and greater fixity of the spermatia, thus making them more like antheridia. In attempting to homologize the spermatia of the Collemaceae and the antheridia of Pyronema, de Bary (11), with his usual morphological acumen, pointed out that 'If the spermatia of Physma remained fixed to their spermatiophores in order to conjugate with the archicarp, the only difference between the two forms would be one of conformation'. In the Collema I have described we have just such a form, and one still more useful for the homology because the spermatia are not borne in spermogonia and are so few in number. In the number and nature of its spermatia and the manner in which they are borne, this species of Collema forms about the most perfect conceivable connecting link between the aquatic red Algae with many non-motile male cells, which are, however, set free, and such terrestrial Ascomycetes as Pyronema and the Mildews, where the male cells are reduced in number to one or two which remain permanently attached.

The conditions as to sexual reproduction in Collema pulposum are also quite the same in principle as those in some of the Laboulbeniaceae, as fully described by Thaxter ( 32 and 33). In Zodiomyces one to three antherozoids bud from the tips of the antheridial appendages. From here the antherozoids fall and are then found lying loose about the bases of the perithecial stalks. The behaviour of the trichogyne is like that of Collema puiposum in that it grows towards where the spermatia are formed and there 
becomes attached to one of them. In Rhynchophoromyces rostratus the small rod-like antherozoids bud distally and laterally from intercalary and undifferentiated cells of the appendages. In some species of Ceratomyces the single rods are replaced by slender long filaments which eventually break up into rods that probably function as antherozoids. Through the motion of the plant the trichogyne is brought into contact with the antherozoids, and Thaxter says it is probable that such antherozoids, in order to be functional, must become detached at the moment when they come in contact with the trichogyne. In the discussion above it was suggested that the greater activity of the trichogyne and the permanent attachment of the spermatia are a result of the land habit. Thaxter suggests that the adherence of the antherozoids to the mother-cell or to one another is an adaptation to ensure fertilization where the antherozoids might otherwise be lost because of the rapidly moving host. This seems entirely reasonable for the special case in question; still, in general, it seems that the production of a large number of free male cells which are carried to the trichogyne in water is characteristic of the aquatic Algae, while the production of few and permanently attached male cells is equally a feature of the terrestrial Fungi. It may be that we have in the genera above mentioned land forms which have later become parasitic on aquatic insects, or it may be, as Thaxter (32) suggests, that we have here an adaptation to an isolated and rapidly moving host.

In a following paper I will describe the development of the apothecium, together with certain nuclear phenomena.

I am greatly indebted to Prof. R. A. Harper, at whose suggestion this work was begun, for helpful advice and criticism.

\section{SumMary.}

I. The spermatia of Collema pulposum are not borne in spermogonia, but are few in number and are borne terminally and laterally on a hypha below the surface of the thallus. They are completely embedded in the thallus and are never set free. They are entirely homologous with the spermatia borne in spermogonia in other species.

2. The carpogones, as in other Lichens, are embedded in the thallus. These consist of a coiled basal portion, the ascogone, and a long terminal structure, the trichogyne. The trichogyne, the end cell of which is exceedingly long, does not grow towards the surface of the thallus and protrude from it, but instead grows more or less horizontally within the thallus towards the region where the spermatia are borne. The sexual apparatus is thus completely submerged in the tissues of the thallus.

3. There is a very evident attraction of the spermatia for the tricho- 
gynes, which is seen in the manner in which the latter converge about a group of spermatia. In growing towards a spermatium and often coiling about it the trichogyne shows a greater activity than that which has been described for other Lichens.

4. The spermatium fuses with the trichogyne to which it has become attached. After this fusion the cross-walls of the cells next to the long terminal cell exhibit the characteristic changes which have been described by other investigators.

5. It is very evident that the spermatia and trichogyne are functional, and that there is not merely a reduced form of fertilization in Collema pulposum.

6. In the number of male cells and the manner in which they are borne Collema pulposum forms an interesting link between the red Algae and such Ascomycetes as Pyronema and the Mildews. In its reproductive structures there are many points of resemblance to such representatives of the Laboulbeniaceae as Zodiomyces and Rhynchophoromyces.

MADISON, Wisc., February, I9I 2.

\section{LITERATURE CITED.}

1. Acharius, Erik.: Methodus qua omnes detectos lichenes secundum organa carpomorpha ad genera, species et varietates redigere atque observationibus illustrare. Stockholm, F. D. D. Ulrich., I 803 .

2. - Lichenographia universalis. Gottingae, Just. Frid. Danckwerts, I 8 Io.

3. : Synopsis Methodica Lichenum. Lundae, Svanborg et Sos., I 8 I 4.

4. Baur, Erwin : Zur Frage nach der Sexualität der Collemaceen. Ber. d. deutsch. Bot. Ges., vol. xvi, 1898 , pp. $3^{6} 3-7$.

5. : Die Anlage und Entwickelung einiger Flechtenapothecien. Flora, vol. 1xxxviii, I901, pp. 319-32.

6. Bot. Ztg., vol. lxii, I904, pp. 2 I-44.

7. Bornet and Thuret : Fécondation des Floridées. Ann. d. Sci. Nat., Bot., vol. vii, sér. 5, I $867, \mathrm{pp}$. г $37-66$.

8. Cornu, M. : Reproduction des Ascomycètes. Ann. d. Sci. Nat., Bot., vol. iii, sér. 6, I 876 , pp. 53-II 2 .

9. Сrombie, J. M. : A Monograph of Lichens found in Britain. I 894.

10. Darbishire, O. V. : Über die Apothecienentwickelung der Flechte Physcia pulverulenta, (Schreb.) Nyl. Jahrb. f. wiss. Bot., vol. xxxiv, I900, pp. 329-45.

11. De BAry, A.: Comparative Morphology and Biology of the Fungi, Mycetozoa, and Bacteria. I 887 .

12. Dillenius, J. J. : Historia muscorum. I74I.

13. FINK, BRUCE : The Lichens of Minnesota. Contrib. from U. S. Nat. Herb., vol. xiv, igio, pp. I-269.

14. Flotow : Lichenologische Beiträge zur Flora Europaea. Bot. Ztg., vol. viii, I850, pp. 553-9.

15. Fries, Elias Magnus : Lichenographia Europaea reformata. Lundae, Typis Berlingianis, I 83 I.

16. Fünfstück, M.: Beiträge zur Entwickelungsgeschichte der Lichenen. Jahrb. d. Kgl. bot. Gartens zu Berlin, vol. iii, 1884 . 
17. Harper, R. A.: Sexual Reproduction in Pyronema confluens and the Morphology of the Ascocarp. Ann. Bot., vol. xiv, I900, pp. 32I-400.

18. : Sexual Reproduction and the Organization of the Nucleus in certain Mildews. Carnegie Inst., 1905 .

19. Hoffmann, Georg Franz: Deutschlands Flora, oder Botanisches Taschenbuch. Erlangen, Johann Jacob Palm, I 795 .

20. Hudson, William : Flora Anglica. 1862.

21. Itzigsohn, Hermann : Die Antheridien und Spermatozoen der Flechten. Bot. Ztg., vol. viii, I 850 , pp. 393-4.

22. vol. viii, I850, pp. 91 3-19.

23. - Bestätigung der Spermatozoen von Borrera. Bot. Ztg., vol. ix, i $8_{5} \mathrm{I}$, pp. I 5 2-4.

24. JANCEWSKi : Morphol. Untersuchungen über Ascobolus. Bot. Ztg., vol. xxix, i87i, p. 257.

25. Kinlmann, O.: Zur Entwickelungsgeschichte der Ascomyceten. Acta Soc. Fennicae, vol. xiii, 1883.

26. Lindau, G. : Über Anlage und Entwickelung einiger Flechtenapothecien. Flora, vol. lxxi, I 888 , pp. 45 I-89.

27. Mudd, William : A Manual of British Lichens. Harrison Penney, Darlington, i86I.

28. Nylander, William : Synopsis Methodica Lichenum. Paris, I858-60.

29. Schaerer, I. E. : Lichenum Helveticorum Spicilegium. 1842.

30. Stahl, E.: Beiträge zur Entwickelungsgeschichte der Flechten. Leipzig, 1877.

31. Sturgis, W. C.: On the Carpological Structure and Development of the Collemaceae and Allied Groups. Proc. Am. Acad. Arts and Sci., vol. xxv, 1890, pp. I5-52.

32. Thaxter, R. : Contributions toward a Monograph of the Laboulbeniaceae. Mem. Am. Acad. Arts and Sci., vol. xii, I895.

33. - Contributions toward a Monograph of the Laboulbeniaceae. Part II. Mem. Am. Acad. Arts and Sci., vol. xiii, I908.

34. Tuckerman, Edward : North American Lichens, I. I882.

35. Tulasne, L. R.: Mémoire sur les Lichens. Ann. d. Sci. Nat., Bot., vol. xvii, sér. 3, 1852, pp. I53-249.

36. : Nouvelles recherches sur l'appareil reproducteur des champignons. Ann. d. Sci. Nat., Bot., vol. xx, sér. 3 , I8 53 , pp. I 2y-183.

\section{EXPLANATION OF FIGURES IN PLATE LXIX.}

Illustrating Miss Bachmann's paper on Collema.

Figs. 2-5 were drawn with the aid of a camera lucida, and have a magnification of 520 diameters.

Fig. I. Diagrammatic representation of cross-section of thallus, showing location of sexual organs and growth of trichogynes towards spermatia.

Fig. 2. Trichogynes converging about a group of spermatia. End of trichogyne fused with spermatium at $a$.

Fig. 3. Few spermatia in group. Cross-walls of cells below terminal cell of trichogyne much thickened. Cells of ascogone somewhat enlarged.

Fig. 4. Several spermatia in group. Ascogone and trichogyne as in Fig. 3.

Fig. 5. Growth of trichogynes towards spermatia. End of trichogyne fused with spermatium at $a$. 
Annats of Botany

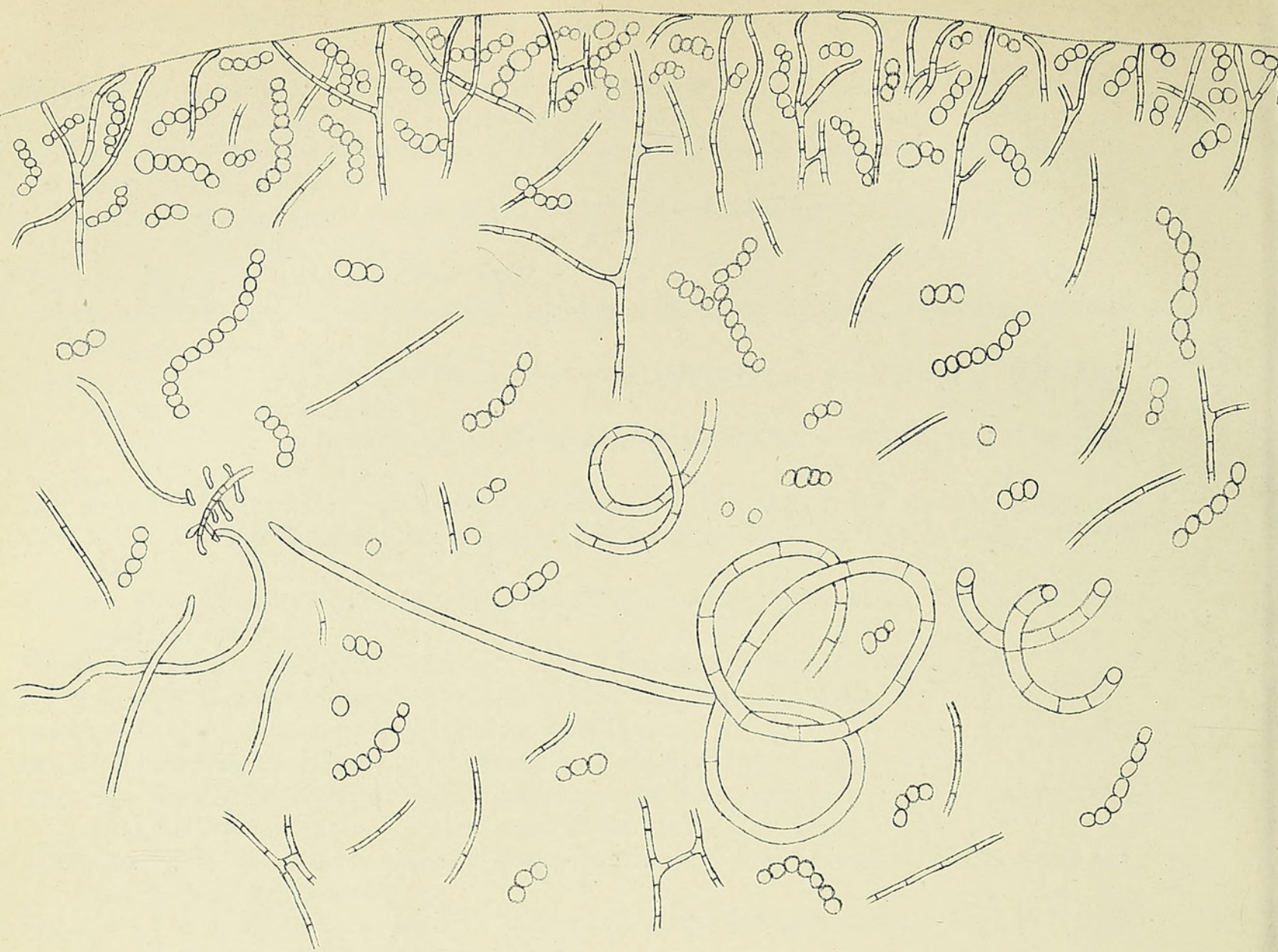

1.
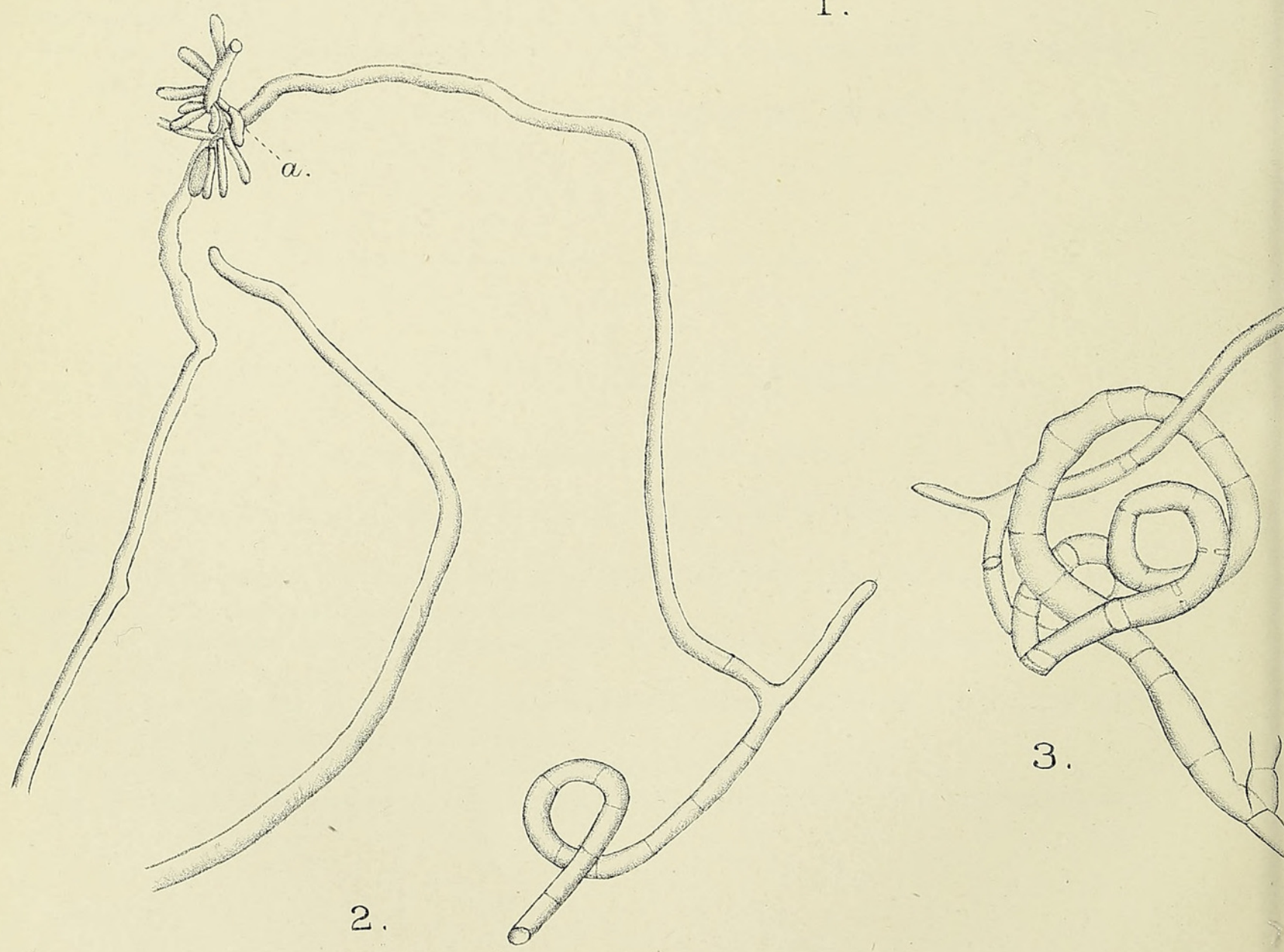

BACHMANN-COLLEMA. 
Vol.XXVI PL.IXIX.

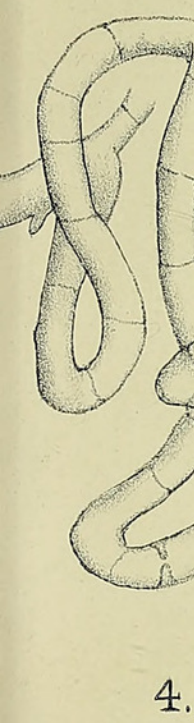

4.

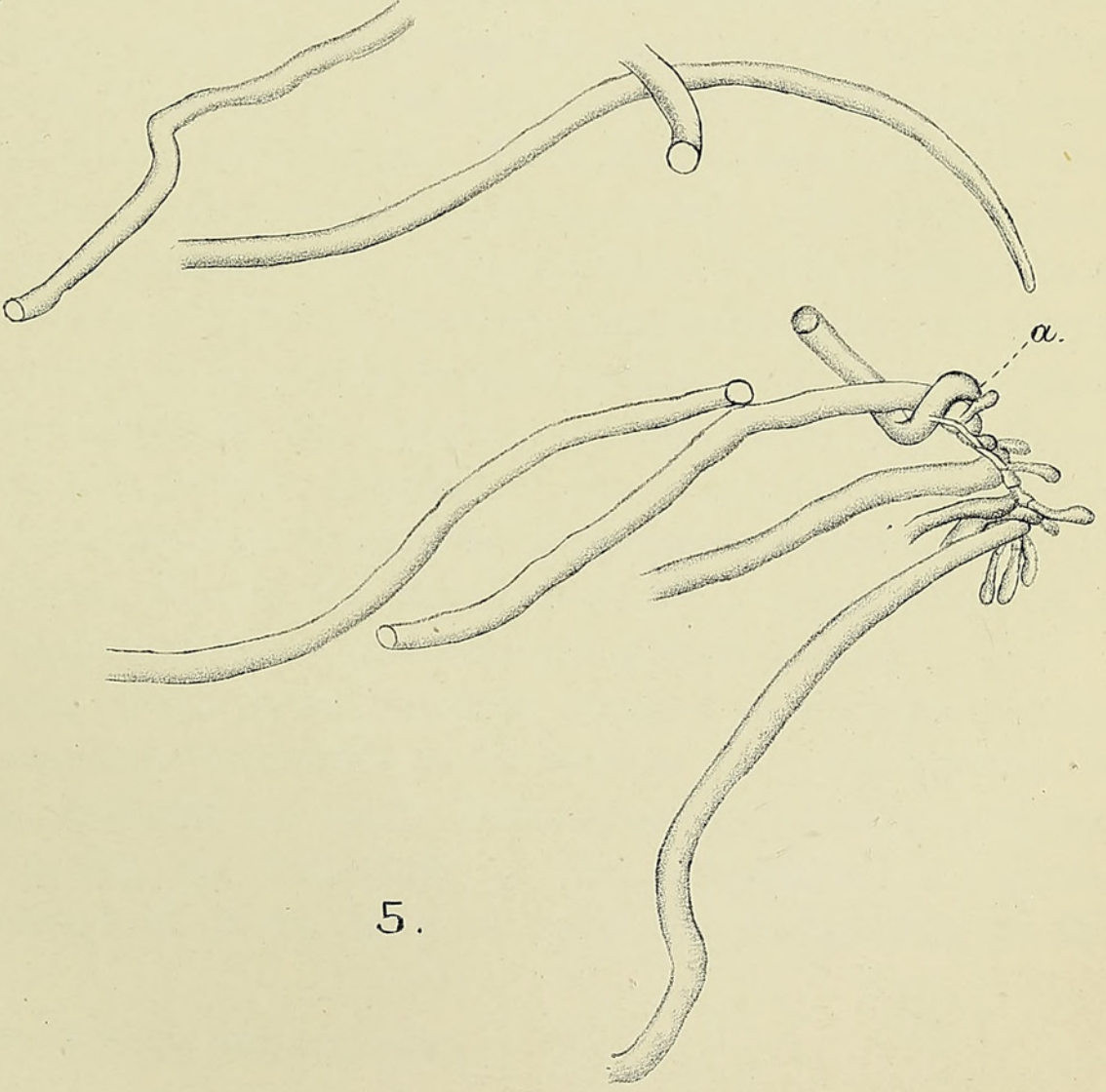

Huth lith. et imp 
Annats of Botany

Vol. XXVI PL.IXIX.
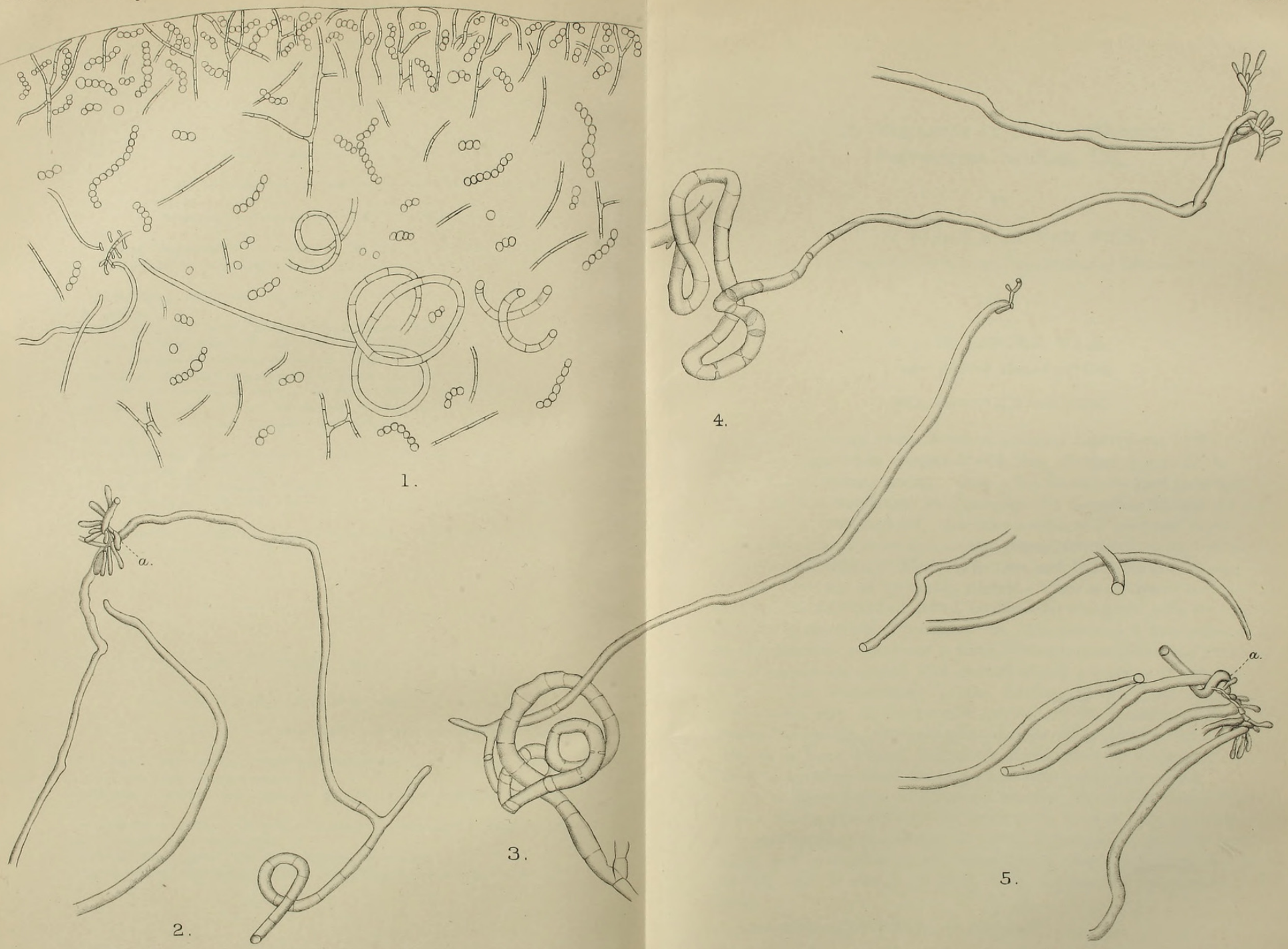

BACHMANN - COLLEMA. 


\section{$2 \mathrm{BHL}$ Biodiversity Heritage Library}

Bachmann, Freda M. 1912. "A new type of spermogonium and fertilization in Collema." Annals of botany 26, 747-760.

https://doi.org/10.1093/oxfordjournals.aob.a089413.

View This Item Online: https://www.biodiversitylibrary.org/item/236930

DOI: https://doi.org/10.1093/oxfordjournals.aob.a089413

Permalink: https://www.biodiversitylibrary.org/partpdf/319926

\section{Holding Institution}

Smithsonian Libraries

\section{Sponsored by}

Biodiversity Heritage Library

\section{Copyright \& Reuse}

Copyright Status: Not in copyright. The BHL knows of no copyright restrictions on this item.

This document was created from content at the Biodiversity Heritage Library, the world's largest open access digital library for biodiversity literature and archives. Visit BHL at https://www.biodiversitylibrary.org. 